Chiara Benassi, King's College London, UK

Lisa Dorigatti, University of Milan, Italy

Published in Work, Employment and Society

Available at https://journals.sagepub.com/doi/full/10.1177/0950017020903039

\title{
Out of sight, out of mind: The challenge of external work arrangements for industrial manufacturing unions in Germany and Italy
}

Work externalisation has challenged the ability of industrial unions to represent workers along the value chain and sustain solidaristic policies, leading to the growing fragmentation of wages and working conditions. This article aims to complement institutionalist analyses of unions' strategies towards peripheral workers by pointing at the role of the labour process. The authors argue that variations in the bargaining strategies and their outcomes for different types of peripheral workers can be explained by observing the extent to which the use of different external work arrangements for specific tasks challenges the logic of industrial unionism. The findings rely on a structured comparison of unions' responses to the use of agency work and on-site subcontracting in four plants owned by two multinational companies in Italy and Germany.

Keywords: labour process, precarious work, trade unions, work externalisation 


\section{Introduction}

Work externalisation fundamentally challenges the traditional representative and bargaining structures of the labour movement in Western democracies. In the Fordist era, workers, while organised on a class basis, developed solidarity within the industrial sectors, and were mainly represented through industrial unions (Streeck, 2005). Such unions represented all workers within the boundaries of vertically integrated companies, 'encompassing workers of all skills and trades and thereby redistributing and equalizing bargaining power between stronger and weaker sections of the workforce' (Streeck, 2005: 267). While union structures remain, to a large extent, similar, vertically integrated firms have been disrupted by work externalisation, which consists of moving work across organizational boundaries and creating networks characterised by market-based relations between organisations (Doellgast and Greer, 2007: 56). The use of these external work arrangements challenges the ability of unions to represent and organise workers along the value chain and to sustain solidaristic and egalitarian policies (Doellgast and Greer, 2007; Hertwig et al., 2018). This has led to the growing fragmentation of employment conditions and wage inequality among the workforce (Marchington et al., 2005; Weil, 2014).

Scholars in the sociology of work and industrial relations have conducted extensive research on whether and how old and new forms of solidarity can be (re)built to resist the fragmentation of work (Alberti al., 2018; Doellgast et al., 2018). One of the central 'puzzles' of this literature is the variation in the strategies adopted by unions towards peripheral, external or atypical workers across workplaces, sectors and countries, both in terms of their inclusiveness and success. Some national- and sectoral-level studies find that the ideological orientations of unions play an important role in union engagement (Author B, 2017; Durazzi, 2017), while others highlight the role of active leadership, innovative strategies and local contingencies (Ibsen and Tapia, 2017). However, most scholars point at the role of institutional factors-e.g. 
if the bargaining power of unions depends primarily on their mobilisation potential (Baccaro et al., 2003), if their institutional power has been eroding (Turner, 2009) or if unions have structures of internal democracy (Marino et al., 2019) - to explain both the likelihood of union intervention and its success (Pulignano et al., 2015; Author A et al., 2016).

The institutionalist analysis of union responses to external work arrangements has largely neglected the role of differences within the 'labour market periphery' in terms of the tasks covered and position of workers within the labour process. This article wants to complement this literature with insights from research on the labour process. Indeed, labour process scholars have traditionally focused on how the organisation of the labour process affects workers' identities and resistance, albeit primarily at the individual level (Martinez Lucio and Stewart, 1997; Marks and Thompson, 2010; Taylor and Moore, 2015). This article argues that insights from the labour process literature are relevant to the employment relations research on union strategies because the way external work arrangements are used and the tasks that they cover challenge, in different ways, the principles of industrial unionism. These principles are at the basis of the identity of many unions (Hyman, 1997), and thus such differences trigger different responses.

Through a systematic comparison of union responses to external work arrangements (agency work versus on-site subcontracting) in two manufacturing multinational corporations (MNCs) in Italy and Germany, this article shows that union engagement depends on the tasks performed by external workers, in particular how 'far' they are from the (perceived) core of the production process.

This article unfolds as follows: in the next section, the challenges posed by work externalisation to structures of traditional representation are examined. Section 3 discusses the negotiated and legal regulation of agency work as well as subcontracting in Italy and Germany, whereas Section 4 illustrates the methodology used. Section 5 presents the empirical findings on the 
bargaining strategies of unions towards agency work and subcontractors. The final section discusses the findings and their implications.

\section{Industrial unionism and external work arrangements}

Industrial unionism is the core principle around which trade unions in most industrialised countries define their organisational structure. The sector and, within it, the company are the key organisational units for industrial unions because they ensure the capacity 'to take wages out of competition all along the (...) production chain' by 'internalizing and thereby suspending conflicts of interest between workers at different stages of the production chain' (Streeck and Visser, 1997: 312f). Following the two key principles of 'equal pay for equal work' and 'one plant, one union', industrial unions represent a heterogeneous pool of workers promoting solidarity-oriented strategies that seek to reduce differences in income and status (Streeck, 2005). Workers performing starkly different activities within the same company are covered by the same agreement and represented by the same union (Hyman, 1997).

While industrial unions typically developed within vertically integrated companies, the use of external work arrangements challenges their ability to organise along industrial lines to regulate employment standards. By moving jobs to sectors in which workers are often poorly organised and lack bargaining power, lead companies can tap into labour market segments characterised by weaker regulation (Doellgast and Greer, 2007; Weil, 2014). At the same time, unions in core companies most often lack bargaining rights over such decisions and their employment-related consequences, and have no legally mandated bargaining rights towards subcontractors (Marchington et al., 2005).

While institutionalised bargaining rights are crucial, institutions do not fully determine the success of unions. Industrial unions have been found to make up for their institutional weaknesses through creative action, e.g. by creatively exploiting existing voice institutions or 
creating new voice channels through mobilisation and lobbying (Turner, 2009; Ibsen and Tapia, 2017). In multi-employer settings, unions in e.g. the German metal and retail sector, and the Danish meat-processing industry have used their resilient power in core companies to negotiate encompassing collective agreements covering subcontractors and staff agencies, even though they lacked formal institutional rights in these matters (Wagner and Refslund, 2016; Hertwig et al., 2018). In other cases, trade unions have forged alliances with local governments and employers to include labour clauses in public procurement contracts (Jaehrling et al., 2018), or formed coalitions with civil society organisations to organise low-wage migrant workers (Alberti et al., 2014).

In light of the above discussion, variations in bargaining strategies and outcomes for peripheral workers cannot be explained only by the strength of institutionalised influence rights of employee representatives on different types of external work arrangements, as argued by e.g. Pulignano and Doerflinger (2018). Unions need to be committed to bargain over external work arrangements because this requires deviating from organisational routines and creatively deploying existing power resources or developing new ones. Employment relations and sociological studies point at the role of the institutional context and union ideologies. In their respective studies on Italian and German unions, Durazzi (2017) and Author B (2017) show that unions with a working-class ideology are more committed to extend their domain of representation beyond the core membership, including agency workers and subcontractors. Other scholars find that unions with institutionalised collective bargaining rights, such as German, Spanish and Italian unions, are less prone to include 'peripheral workers' than unions in the US and UK because their power does not depend on membership numbers and mobilisation (Baccaro et al., 2003). However, scholars also show that traditionally strong unions turn to represent peripheral workers when their institutional power resources are in decline (Turner, 2009). These explanations, however, fall short of explaining why the same 
union might target only specific groups of workers on external work arrangements, or vary its approach to the same contractual category of workers across workplaces.

This article argues that the debate on unions and peripheral workers would benefit from a greater engagement with the structure of the labour process, and particularly with how different types of external work arrangements are used in the workplace. Labour process researchers have typically examined how labour is controlled and organised in order to produce value and its implications for workers' resistance (Thompson and Smith 2009). In their seminal work, Gordon et al. (1982) claim that divisions among workers in their production experiences, which are shaped by employers' segmentation strategies, foster the development of divergent attitudes and orientations among the workforce, thereby affecting their capacity for resistance. Indeed, labour process scholars claim that solidarities between workers develop at the point of production, and are strengthened by their common experiences in the labour process (Marks and Thompson, 2010; Taylor and Moore, 2015). Yet, this literature, especially in its more recent contributions, has focused on the individual level, and has thus neglected the collective and organised dimension of labour as well as the politics of the employment relationship at the meso level, in particular the role of unions (Martinez Lucio and Stewart, 1997).

Still, the argument that commonalities in the labour process between workers matter for the processes of identity formation and resistance can also be applied to the meso level to understand unions' responses to external work arrangements. It is indeed crucial to consider how the use and position of external work arrangements within the labour process challenge the logic of action of industrial unions - as 'the more a challenge impairs a union's capacities to pursue its core strategies successfully, the higher the priority it assigns to addressing the challenge' (Holst, 2008: 28). By externalising work, employers redefine the boundaries of the firm and, thus, the constituencies unions represent (Streeck and Visser, 1997). However, external work arrangements that do not involve workers performing tasks similar to those 
performed by 'core' workers in the sector or the company do not critically question the principles of industrial unionism and, in particular, the principle of 'equal pay for equal work'. Hence, these workers might be legitimately assigned to other sectoral unions without disrupting the traditional logic of action. By contrast, external work arrangements that affect core functions within the sector/company challenge the key organisational principle and core strategies of industrial unions aimed at taking wages out of competition. Therefore, these work arrangements are more likely to trigger union responses.

\section{Challenges of agency work and subcontracting for unions in Italy and Germany}

The relationship between the use of external work arrangements and union responses is explored by looking at the bargaining efforts of German and Italian manufacturing unions in two forms of external work arrangement, agency work and on-site subcontracting.

The two contractual forms differ in terms of the degree of control employers exert over workers (Cappelli and Keller, 2013). Even if directly employed by an agency, agency workers are under the direct control of the client company and so are most often employed in production tasks closely interconnected with those of directly employed workers. Workers in subcontractors are under the control of their employer-the subcontractor-and so are mostly concentrated in activities that do not require direct instructions from the lead employer. Still, even though subcontracting arrangements should be used for self-contained tasks, employers have been found to also employ subcontractors in a relationship of direct control, fictitiously 'breaking up' the production process (Helfen et al., 2017; Moore and Newsome, 2018) or even breaking the law (Hertwig et al., 2018).

The two arrangements also differ in the level of influence unions can have in the workplace, limited as it is in both cases. In Italy, unions have only right to information on agency work and subcontracting. The law and the metal collective agreement define rights to information on 
agency work as yearly communication from the management regarding the number of workers employed, lengths of their contracts, and their qualifications. By contrast, workers' representatives need to be informed only if subcontracting implies a transfer of employees. However, the metal collective agreement extends information rights to all other subcontracting decisions and sets provisions limiting subcontracting, banning it from 'core' activities such as ordinary maintenance carried out during normal working hours, and limiting it to technical, organisational, managerial and economic reasons that can be jointly examined by employee representatives. Moreover, the metal agreement forces companies to require from subcontractors the application of collective agreements, though not necessarily the metal agreement.

In Germany, works councils have legal information rights on the employment of agency workers, to which they can object under specific circumstances, including if it constitutes a threat to the company's workforce (e.g. if permanent workers are at risk of dismissal, which is, however, difficult to prove); and if the employer did not provide the information in the first place. Furthermore, since 2011, a (vague) legal provision allows works councils to stop the hiring of agency workers if their employment is not 'temporary'. Finally, the works council has codetermination rights on the working time and work organization of agency workers. By contrast, works councils have only rights to information on the costs and the tasks covered by subcontractors. It also has the right to suggest an alternative plan to externalisation but the employer is not obliged to follow it.

\section{Cases and methodology}

This study compares four plants - two in Germany and two in Italy - belonging to two MNCs with their headquarters respectively in Germany and in Italy. The labour movements in Germany and Italy are characterised by a tradition of industrial unionism; therefore, the use of 
agency work and subcontracting represents similar challenges to the unions. The MNCs specialised in machine tools and special vehicles and the plants were selected because they focus on production (only one plant also had a small $R \& D$ centre) and were similar in terms of product and market segment. Thus, the technology, work organisation, skill requirements and competitive pressure were also broadly comparable.

Consequently, the plants were also similar in terms of how external work is used (see Table 1). In three cases, agency work was used mainly at the assembly line, as a recruiting channel and a flexibility buffer. In GERMETAL-DE, there was no agency work due to the resistance of the works council (see next section). All plants used subcontracting for low-end services, such as facility management and building maintenance, catering and security. In the German plants, subcontractors were also used for machine maintenance (for a few years in GERMETAL-DE), packaging and small pre-assembly jobs (GERMETAL-DE) and engineering and vehicle pasting (ITALMETAL-DE). In GERMETAL-IT, subcontractors were used for quality control activities for a limited period.

\section{Table 1 about here}

The authors conducted 45 interviews with union representatives and works councillors in the German and Italian manufacturing industries between 2012 and 2014, which provided the first evidence for a systematic variation in union responses between agency work and subcontracting. To further explore these initial findings, the authors returned to the field between 2016 and 2017 to collect data on two newly selected and matched MNCs, and conducted 28 face-to-face and phone interviews with human resource managers, union representatives involved in plant-level negotiations and workplace representatives. Among those, interviews with three workers' representatives were conducted during a protest 
demonstration in one of the plants, which one of the authors attended to ease the access to the works council. Three site visits (between one and three hours) in the German plants were also carried out, which helped obtain a better understanding of the structure of production. The interviews primarily focused on the use of external work arrangements in the workplace and on the content and process of collective bargaining, and explored the conditions under which unions decided to oppose managerial strategies and negotiated collective agreements.

The interviews were conducted in the native language of the interviewees and fully transcribed, and were later analysed through NVivo. The authors collaboratively developed the nodes from the literature and the first round of fieldwork, which they used to describe and categorise the data. As the analysis of interview data progressed, nodes were then discussed again as new elements emerged and the authors started identifying the connections between different nodes. The 'free nodes' (without any shape for a node system) were then grouped into hierarchical structures called 'tree nodes' according to thematic areas, including the elements of the negotiated regulation for agency workers and subcontractors; the attitudes of workers' representatives towards agency work and subcontractors; the institutional and contingent power resources unions used for regulation.

\section{Findings}

\subsection{Variation in bargaining outcomes}

Bargaining outcomes on external work arrangements showed both similarities and differences between the countries and the groups of external workers under scrutiny.

In ITALMETAL-DE, the works council had bargained a workplace agreement on agency work in 2005, whereby agency workers would be paid according to the metal agreement while working on site. It also prevented the company from hiring workers from staff agencies who did not apply the collective agreement for the agency sector. Following the IG Metall collective 
agreement on agency work in 2012, the workplace agreement implemented a system of wage bonuses that reduced the gap between the salary of the agency and that of permanent workers. At GERMETAL-DE, agency work was not allowed because the works councils at the local and central level had always opposed it. The ban was not set through a collective agreement but based on informal understanding.

In both Italian plants, emphasis was placed on mechanisms ensuring the transition of agency workers to permanent employment, as the law had already set the right to equal pay and treatment. In ITALMETAL-IT, no formal agreement was in place, but until 2010 employee representatives were able to ensure the transition from agency to permanent contracts by bargaining ad-hoc stabilisations. However, informal bargaining stopped in 2010 due to a deterioration in workplace-industrial relations (see next section). The regulation of agency work in GERMETAL-IT was characterised by three phases. Until 2014, the management used to directly hire agency workers after 36 months of assignment under the supervision of the union, but instructions to reduce the headcount from the German headquarters imposed the unilateral termination of this practice in 2014 , when the company started using staff leasing. In 2017, workplace representatives bargained an agreement setting a maximum quota of nonpermanent employment ( $25 \%$ for both agency workers and fixed-term contracts) and a transition mechanism from agency to permanent contracts: Agency workers have to be permanently hired after 36 months of direct assignment and, after 18 months of assignment, enter a pool that the company has to draw from when necessary.

With regard to subcontractors in low-end services, the engagement of works councils in the German MNC plants was limited. They made no concrete attempts to regulate these workers' wages and working conditions, and did not know in most cases whether they were covered by collective agreements. Only at GERMETAL-DE the works council supported the initiative of subcontracted workers to set up a works council, which then negotiated the application of the 
collective agreement for the logistic sector, that is inferior to the metal agreement. Most subcontractors in both plants, however, were covered only by the national minimum wage, which came into effect in 2015. In particular, but not exclusively, in times of crisis, works councils tried to re-internalise jobs in production-related functions, such as maintenance, production (vehicle pasting) and engineering, enforcing their rights to enquire about subcontracting decisions and providing cost-benefit analyses based on data from management. Only maintenance jobs in GERMETAL-DE had been re-internalised.

In Italy, the regulation of subcontractors mostly focused on wages and working conditions. In GERMETAL-IT, a workplace agreement was bargained in 2017, granting employee representatives information rights on subcontractors and defining a procedure of joint evaluation in case the service was assigned to a new subcontractor to ensure the continuity of employment to incumbent workers. Moreover, it required that the company use subcontractors applying collective agreements signed by unions belonging to the three major confederations. Stronger action was undertaken by employee representatives in GERMETAL-IT concerning production-related activities: the subcontracting of quality control activities was successfully opposed and these jobs were reinternalized. No negotiated provision concerning on-site subcontracting was, instead, present in ITALMETAL-IT, even though employee representatives supported workers in low-end subcontractors when asked for help.

To sum up, in both countries, the negotiated regulations were stricter and more encompassing for agency workers than for subcontractors, especially those employed in low-end industrial services. However, there were cross-country differences concerning the content and strength of the regulations. In Italy, agreements on agency work focused on limiting employer discretion because of already existing equal treatment legislation, whereas those in the German plant ITALMETAL-DE included the employment conditions of agency workers. The regulation of subcontractors involved working conditions in Italy, where subcontractors were mostly limited 
to non-core activities, whereas in Germany, the works councils focused on limiting subcontracting, and only when it was used for performing core tasks. Moreover, there was cross-national variation concerning the strength of regulation, particularly on agency work, as German plants are characterized by stricter workplace regulations than Italian plants (see Table 2).

\subsection{The bargaining process: Re-inventing institutional power}

As mentioned in Section 3, institutionalised voice rights on the use of external work arrangements were limited in both countries. Still, employee representatives managed to regulate agency work and some subcontractors using their institutionalised voice rights in other domains, especially in terms of working time. Table 2 provides an overview of the collective bargaining outcomes (illustrated in the previous section) and collective bargaining strategies, which are discussed here in greater detail.

\section{Table 2 about here}

In ITALMETAL-IT, the ability of employee representatives to regulate external work arrangements was closely connected with their influence on the working time of permanent workers. The metal agreement included up to 40 hours per year of compulsory overtime on Saturdays. Additional overtime needed to be negotiated with employee representatives. Thus, employee representatives in ITALMETAL-IT could exchange additional overtime against the transition of agency workers to permanent employment, as explained by an employee representative:

'[T]here was the opportunity to transform those (agency) workers in exchange of 
overtime on Saturdays, beyond those (Saturdays) which had already been agreed upon in the sectoral agreement' (ITALMETAL-IT FIOM employee representative, 30 September, 2016).

Collective bargaining rights over working time were so crucial that negotiating over agency work became more difficult after 2010, when the company withdrew from the sectoral collective agreement and introduced 120 hours of obligatory overtime per year through a new company-level agreement signed by only two of the three confederal unions.

Similarly, in GERMETAL-IT bargaining rights concerning the working time of permanent workers were used to regulate external work arrangements. In 2017 , as the company wanted to introduce a new system of 18 eight-hour shifts a week including Saturdays, employee representatives negotiated, among other things, agency workers' transition to permanent contracts, the end of staff leasing and provisions regulating the working conditions of on-site subcontractors in exchange for their agreement to the new system. An employee representative described this exchange as follows:

'[T]his agreement finds its roots into the company's necessity to ensure a more complete utilisation of production facilities, also creating a new shift system (...). The company had a strong interest in that (...) [,] and the trade unions were interested in regulating external work (...) [.S] there was an exchange' (GERMETAL-IT UILM trade unionist, 24 August, 2017).

Even before the agreement had been negotiated, employee representatives had supervised the use of agency work, in particular the transition to permanent employment after 36 months of assignment. When the company did not respect the informal transition rule, employee 
representatives relied on a variety of power resources to strengthen their voice. Institutionalised rights on overtime work were, again, important as well as the mobilisation of the permanent workforce. For example, a major conflict took place in 2013, when the contracts of five agency workers were terminated even though they had been working at the company for some years, and were close to the 36-month threshold. Employee representatives called for two strikes, both highly participated by permanent workers, thus forcing the company to withdraw its decision. However, once the company stopped directly hiring agency workers and started using staff leasing, unions could not enforce agency workers' transition to permanent employment anymore.

In ITALMETAL-DE, the works council bargained an agreement on agency work in 2005, two years before the IG Metall campaign led to the abovementioned sectoral agreement in 2012 . At the time, the company had been expanding, and was setting up a second shift, where they had employed 400 agency workers, mainly at the assembly line, who were being paid significantly less than their colleagues. Given the short period of time available for staffing, the second shift and the low unemployment rate of the region, the works council acknowledged that agency work was the best solution but asked that it be regulated. To achieve regulation in areas such as agency workers' wages, working conditions and transitions to permanent contracts, where it did not have codetermination rights, the works council took advantage of the time pressure the management was under to arrange new shifts and quickly staff themwhich would have been impossible without their cooperation - and exchanged their consent in other areas, in particular in terms of working time. When asked how they had managed to bargain on external work arrangements, a works councillor from ITALMETAL-DE explained:

'You take into consideration other things. Overtime? No, I don't want it. Or productivity changes? No, I don't want it [...] And you look for other issues where you can have the 
conflict, and then $[\ldots]$ a works council needs to say "you help me a bit with agency work or subcontracting, and then I'll help you. And if you don't, then...”. It's just a conflict' (ITALMETAL-DE works councillor, 07 September, 2016).

Interestingly, the works councillor also mentioned subcontracting, even though there was no agreement on the issue at the time, and the works council did not report any instance where they had threatened to withdraw their cooperation on working time if they had not had the subcontracting regulated.

In GERMETAL-DE, the works council imposed a ban on the employment of agency workers. The management accepted it because they knew that 'the works council would not be a part of that' (GERMETAL-DE MGMT, 25.10.2016). The works council has traditionally had a cooperative relationship with management, which is supported, however, by the (threat of) industrial action, mobilisation or withdrawal of cooperation if the management is not ready to negotiate. This labour-management relationship reflects the traditional German Konfliktpartnerschaft (Müller-Jentsch, 1991). In interviews, the works councillors stressed the importance of mobilisation and activism for regulating external work arrangements, including union meetings, works council meetings and going public through media engagement and demonstrations to put the management under pressure. Similar to the other cases, they mentioned the withdrawal of works councils' cooperation on working time as crucial:

'[W]hen we get a request of overtime, we say, "no, you don't need it. If you want to use subcontractors, if you want to use agency workers, then you don't need overtime' (GERMETAL-DE works councillor, 13 October, 2016). 


\subsection{Union engagement with 'productive' workers}

Across the cases, unions engaged differently with agency workers and subcontractors, as shown in Table 2. This article argues that this has depended on the varying integration of the two external work arrangements in the labour process: agency workers often perform 'core activities' while subcontractors are mostly concentrated in activities perceived as 'non-core', not only by the management but also by workers' representatives. Indeed, unions have taken the initiative on subcontractors when they were used in areas perceived as 'core'.

Employee representatives in both Italian MNCs explained their limited engagement in regulating subcontractors by arguing that subcontracting is relatively marginal, both in terms of the number of workers involved and the activities performed. For instance, an employee representative explained:

'Concerning the situation of on-site subcontractors (...) we are relatively lucky. We have 7-8 people at the reception, 4-5 employed for the security, 4-5 for cleaning activities and around 20 in maintenance. They do not produce, they are not in the offices (...). We have negotiated information rights, to know what they do, but we still talk of only a few people. (...). Their number grows, those in maintenance are increasing, but we are still talking about maintenance, they do not produce' (GERMETAL-IT FIOM employee representative, 02 September, 2016).

In both MNCs, subcontracting was limited to non-production activities, such as cleaning, security, catering and limited maintenance activities. Only in GERMETAL-IT did the management try to use subcontracting for the skilled production-related tasks of quality control, but this was soon stopped by the union, which successfully requested the employment of agency workers in place of subcontractors. An employee representative explained the union 
intervention on account of the fear that on-site subcontracting might have been the first step of a full externalisation of quality control, which would have undermined the position of production workers and the capacity of the union to set standards for them:

'There was a peak in quality control activities and they outsourced it to an external company. But we immediately stopped them. We were very careful, because when you see people dressed differently than you, you get immediately worried, because it takes a second to trigger a chain reaction (...). If we outsource quality control, we could lose 5060 people' (GERMETAL-IT FIOM employee representative, 2 September 2016).

The nature of externalised tasks worked as a trigger for union engagement with subcontracting, and this mechanism became even clearer when compared with the lack of union opposition when the management proposed subcontracting other low-end activities. In this case, subcontracting was not perceived as dangerous for permanent employees, as explained by a union representative:

'If we get new investments and new products, the fact that you outsource some activities without transferring personnel, which would be additional, well, this is not so problematic' (GERMETAL-IT UILM trade unionist, 24 September, 2017).

Moreover, employee representatives seemed to share the understanding that non-metal subcontracted workers did not necessarily belong to their domains of representation. Since they did not perform metal-related tasks, they belonged to other industries and, therefore, were represented by other unions. As stated by an FIM union official responsible for workplace negotiations at ITALMETAL-IT, 
' working conditions (of on-site subcontractors) are negotiated with the responsible trade union and not with the trade union of the metal sector (...). Bargaining on behalf of those workers is responsibility of the union [,] which represents workers doing such activities' (ITALMETAL-IT FIM trade unionist, 25 August, 2017).

Therefore, employee representatives consider it normal that these workers fall outside the domain of the metal collective agreement, and are not included in negotiations at the sectoral or company level, even though they were part of the same agreements and unions when those activities had been performed within the company. When employee representatives engaged with low-end subcontractors, as in the case of GERMETAL-IT, they did so to prevent abuses often connected with work externalisation processes, and to ensure the application of the collective agreements signed by confederal trade unions of their respective sectors:

'I have to say that employee representatives in this plant are very active for what concerns the application of collective agreements (...). But those subcontracting agreements are really confined to those activities which are not proper of a metal company, to service activities' (GERMETAL-IT UILM trade unionist, 24 August, 2017).

Similarly, in the two German plants, the workers' representatives distinguished between 'production' and 'skilled work' (Facharbeit) as core activities and 'industrial services', the latter of which could be externalised to subcontractors (GERMETAL-DE works councillor, August 31, 2016; IGM trade unionist, May 25, 2016). During site visits, the works councillors were not always confident whether workers in certain areas (e.g. security or recycling) had been employed by subcontractors, suggesting that this was not their top bargaining priority. In 
both plants, subcontractors were mainly concentrated in catering, security, maintenance and cleaning of machines and facilities, and parts of the logistic and recycling. In some cases, these were jobs that permanent workers did not want, e.g. cleaning the machines was defined as an 'easy and dirty job'. Hence, re-internalising these peripheral jobs would 'be no solution for their people' (emphasis added), even during economic downturns because those jobs did not reflect the skills of metal workers (GERMETAL-DE works councillor, 8 August, 2016).

However, works councillors in both plants started contesting externalisation and requesting the re-insourcing of subcontracted activities closer to activities perceived as core. In the last few years, some subcontractors at GERMETAL-DE have started offering pre-assembly services in addition to packaging (which the company used to do internally), delivering components to the assembly line, and maintenance. In the past four or five years at ITALMETAL-DE, the management has externalised the function of vehicle pasting and $R \& D$ projects to on-site subcontractors. Initially, the (non-)response of worker representatives was similar to that of their Italian colleagues, as the management justified the employment of subcontractors for 'value-added' activities as a buffer to catch demand surplus. Therefore, subcontracting was seen as a relief to the core workforce, as this quote of an IG Metall representative suggests:

'[T]hey (works councillors) did not find it [regulating subcontractors] so important because the production was going upwards. And as long as the company created new workplaces, it did not interest our works councillors what it's been done in regard to subcontracting' (GERMETAL-DE IGM trade unionist, 25 May, 2016).

The workers' representatives started paying more attention when they realised that more and more 'value' was being produced by subcontractors while their companies were experiencing downsizing owing to difficult market conditions and, in the case of GERMETAL-DE, to the 
management intentions to shift part of the production to their Italian sister plant. While subcontractors were allegedly used as a buffer, once demand had peaked, the value-added segments remained outside the organisational boundaries, thus shifting core jobs outside the control of the works councils and undermining employment in the company. As production slowed down, the works council in ITALMETAL-DE started enquiring into the use of subcontractors for vehicle pasting, which had been newly outsourced, and for R\&D. In the R\&D business unit, the company used agency workers until 2013, when it started employing subcontracted engineers working from a separate office on site to reduce headcount. The works council tried to bring the work back in-house by making the argument to the supervisory board and the bipartite economic committee that subcontracting is more expensive than re-insourcing. Thus far, this has been unsuccessful and, during a second plant visit (around a year after the first visit), a works councillor said, while laughing, that 'the van (of the vehicle-pasting subcontractor) is still there' (09 May, 2017). Similarly, the separated office was still occupied by subcontracted engineers.

The timing of the response to subcontracting was revealing when compared with the reaction to agency workers in ITALMETAL-DE. As mentioned in Section 5.2, the works council used the production peak as window of opportunity to bargain a collective agreement regulating agency workers' wages and working conditions; by contrast, they started engaging with subcontracting only when production went down, and, even then, the attempt towards reinternalising subcontractors was concentrated only on tasks perceived as value added and suitable for their core workers.

German workplace representatives were aware that subcontractors were not represented by other unions or covered by collective agreements, but did not try to extend coverage through clauses forcing subcontractors to apply to other sectoral agreements, as in the Italian case. They also refused agreements setting lower wages and working conditions for industrial services as 
an instrument for preventing the externalisation of core activities, focusing instead on extending codetermination rights on subcontracting decisions. Service agreements were seen in opposition to the principle of 'one plant one union', as illustrated by a works councillor in ITALMETAL-DE:

'I could never explain to the people in the logistics, "you are now under a service agreement, you get less money than the colleagues at the assembly line, because you are not in the same collective agreement". And they (the logistics workers) say, "yes, but we are one company. We are still in one company, aren’t we? "' (ITALMETAL-DE works councillor, 07 July, 2016).

Hence, inaction seemed to be the preferred political strategy. Only in case of one logistic subcontractor at GERMETAL-DE did the works council take action in support of subcontracted workers by helping them to hold elections to establish a works council. This solidarity-oriented initiative came about as a result of personal contact between the head of the GERMETAL-DE works council and the (now) head of the works council at the subcontractor when they had worked together as forklift operators. The works council did not try to extend the IG Metall collective agreement to the subcontractor but the newly established works council forced the management to apply the sectoral agreement of the construction and logistics' sector, which is however characterised by lower standards than the metal agreement.

\section{Discussion and conclusions}

This article contributes to the academic debate on whether and how unions can (re)build workplace solidarity to resist the fragmentation of work (Alberti al., 2018; Doellgast et al., 2018) by highlighting the role of the position of external work arrangements in the labour process to explain union responses. The variation in union responses has most often been 
explained through institutional power resources, which have historically developed within the institutional context (Author A et al., 2016; Pulignano et al., 2015). In line with this research, findings show that institutional power resources, such as collective voice rights in the workplace, support greater success in regulating external work arrangements in Germany than in Italy. Institutionalist explanations, however, fall short at explaining why unions' efforts proved to be stronger and more effective for agency workers than for on-site subcontractors.

While some authors have tried to explain this variation by observing collective bargaining rights concerning different types of external work arrangements (Pulignano and Doerflinger, 2018), our evidence suggests that they are limited for both types of arrangements (see Section 3). Indeed, even though unions have slightly stronger bargaining rights concerning agency work, they have relied on their institutionalised bargaining rights in other domains — especially working time and mobilisation to bargain regulation. Therefore, a similar exchange could have taken place also to regulate subcontracting (see, e.g. Doellgast and Berg, 2017; Hertwig et al., 2018).

This article argued that institutionalist explanations of union responses can be fruitfully integrated with insights from labour process theory, as the findings presented here can be better understood by observing the dynamics developing at the point of production (Thompson and Smith, 2009), particularly the role of employers' segmentation strategies that create divisions between workers and affect their experience of the labour process (Gordon et al., 1982). Labour process scholars have focused on the individual level, observing how workplace segmentation affects workers' identities as well as their ability and willingness to organise and mobilise (Marks and Thompson, 2010; Taylor and Moore, 2015). However, the authors here argued that workplace segmentation via externalisation also has an impact on the unions' identities and logics of action. The case studies suggested that unions try to regulate external work arrangements or re-internalise tasks when their use is perceived to contravene the core 
principles of industrial unionism.

Thus, this article contributes to research on trade union strategies towards peripheral workers (e.g. Doellgast et al., 2018) by showing that it is important to include the structural characteristics of the labour process in the analysis to better understand the obstacles to union solidaristic policies. By applying the argument from labour process theory at the meso level to advance (institutionalist) employment relations research on unions, this article demonstrates the value of cross-fertilization between the two research streams as advocated by Hauptmeier and Vidal (2014).

On a concluding note, it is worth noting that our argument is not intended to deterministically predict the demise of inclusive unions in the context of work externalisation. The identities and logics of unions are fluid, and they can redraw their boundaries of representation (Hyman, 1997). However, the growing use of external work arrangements requires that unions overcome the limitations that the traditional logic of industrial unionism poses to broader definitions of union constituencies - in particular their focus on the company as key organisational principle — and to reframe their 'core' constituencies to be able to represent workers who are more 'out of sight' than others. Research on these first attempts by unions has shown, for instance, that some unions are trying to adopt a 'political' rather than juridical concept of the firm, which does not cover only direct employees, but all those involved in the labour process (Author B, 2017). 


\section{References}

Alberti G, Bessa I, Hardy K, Trappmann V, and Umney C (2018) In, against and beyond precarity: Work in insecure times. Work, Employment and Society 32(3): 447-457.

Alberti G, Holgate J, and Turner L (2014) Opportunity and choice for unions organizing immigrant workers. In: Adler LH, Tapia M, Turner L (eds) Mobilizing against Inequality, Ithaca: Cornell University Press, 109-130.

Baccaro L, Hamann K, and Turner L (2003) The politics of labour movement revitalization: The need for a revitalized perspective. European Journal of Industrial Relations 9(1): 119133.

Cappelli P, Keller JR (2013) Classifying work in the new economy. Academy of Management Review 38(4): 575-596.

Doellgast V, Lillie N, Pulignano V (2018) Reconstructing Solidarity: Labour Unions, Precarious Work, and the Politics of Institutional Change in Europe. Oxford: Oxford University Press.

Doellgast V, Berg P (2017) Negotiating flexibility: external contracting and working time control in German and Danish telecommunications firms. ILR Review 71(1): 117-142.

Doellgast V, Greer I (2007) Vertical disintegration and the disorganization of German industrial relations. British Journal of Industrial Relations 45(1): 55-76.

Durazzi N. (2017) Inclusive unions in a dualized labour market? The challenge of organizing labour market policy and social protection for labour market outsiders. Social Policy \& Administration 51(2): 265-285.

Gordon DM, Edwards R, and Reich M (1982) Segmented Work, Divided Workers: The Historical Transformation of Labor in the United States. New York: Cambridge University Press. 
Hauptmeier M, Vidal M (2014) Comparative Political Economy of Work. Basingstoke: Palgrave Macmillan.

Helfen M, Nicklich M, and Fortwengel J (2017) Enacting global competition in local supply chain environments: German "Chemieparks" and the micro-politics of employment relations in a CME. International Journal of Human Resource Management 28(8): 2656-2683.

Hertwig M, Kirsch J, and Wirth C (2019) Defence is the best offence: Horizontal disintegration and institutional completion in the German coordinated market economy. Work, Employment and Society 33(3): 500-517.

Holst H (2008) The political economy of trade union strategies in Austria and Germany: The case of call centres. European Journal of Industrial Relations 14(1): 25-45.

Hyman R. (1997). Trade unions and interest representation in the context of globalisation. Transfer 3(3): 515-533.

Ibsen CL, Tapia M (2017) Trade union revitalisation: Where are we now? Where to next? Journal of Industrial Relations 59(2): 170-191.

Jaehrling K, Johnson M, Larsen TP, Refslund B, and Grimshaw D (2018) Tackling precarious work in public supply chains: A comparison of local government procurement policies in Denmark, Germany and the UK. Work, Employment and Society 32(3): 546-563.

Marchington M, Grimshaw D, Rubery J, and Willmott H. (2005) Fragmenting Work: Blurring Organizational Boundaries and Disordering Hierarchies. Oxford: Oxford University Press. Marino S, Bernaciack M, Mrozowicki L, and Pulignano V (2019) Unions for whom? Union democracy and precarious workers in Poland and Italy. Economic and Industrial Democracy 40(1): 111-131.

Marks A, Thompson P (2010) Beyond the blank slate: Identities and interests at work. In: Thompson P, Smith C (eds.) Working Life: Renewing Labour Process Analysis. Basingstoke: Palgrave Macmillan. 
Martinez Lucio M, and Stewart P (1997) The paradox of contemporary labour process theory: The rediscovery of labour and the disappearance of collectivism. Capital \& Class 21(2): 4977.

Moore S, Newsome K (2018) Paying for free delivery: Dependent self-employment as a measure of precarity in parcel delivery. Work, Employment and Society 32(3): 475-492.

Müller-Jentsch W. (1991) Konfliktpartnerschaft: Akteure und Institutionen der Industriellen Beziehungen. Frankfurt: Hampp Verlag.

Pulignano V, Meardi G, and Doerflinger N (2015) Trade unions and labour market dualisation: A comparison of policies and attitudes towards agency and migrant workers in Germany and Belgium. Work, Employment and Society 29(5): 808-825.

Pulignano V, Doerflinger N (2018) Labour markets, solidarity, and precarious work. Comparing local unions' responses to management flexibility strategies in the German and Belgian metalworking and chemical industries. In: Doellgast V, Lillie N, Pulignano V (eds) Reconstructing Solidarity: Labour Unions, Precarious Work, and the Politics of Institutional Change in Europe. Oxford: Oxford University Press.

Streeck W (2005) The sociology of labor markets and trade unions. In: Smelser NJ, Swedberg R (eds) The Handbook of Economic Sociology. Princeton: Princeton University Press.

Streeck W, Visser J (1997) The rise of the conglomerate union. European Journal of Industrial Relations 3(3): 305-332.

Taylor P, Moore S (2015) Cabin crew collectivism: Labour process and the roots of mobilization. Work, Employment and Society 29(1): 79-98.

Thompson P, Smith C (2009) Labour power and labour process: Contesting the marginality of the sociology of work. Sociology 43(5): 913-930.

Turner L (2009) Institutions and activism: crisis and opportunity for a German labor movement in decline. ILR Review 62(3): 294-312. 
Wagner I, Refslund B (2016) Understanding the diverging trajectories of slaughterhouse work in Denmark and Germany: A power resource approach. European Journal of Industrial Relations 22(4): 335-351.

Weil D (2014) The Fissured Workplace Cambridge: Harvard University Press. 
Table 1. Overview of case studies

\begin{tabular}{|c|c|c|c|c|}
\hline & \multicolumn{2}{|c|}{ ITALMETAL } & GERMETAL & \multirow[b]{2}{*}{ DE } \\
\hline & IT & DE & IT & \\
\hline Plant & Production & Production and R\&D & Production & Production \\
\hline Size & $>1800$ & $>1100$ & $>600$ & $>700$ \\
\hline Industrial relations & $\begin{array}{l}40-50 \% \text { union density } \\
\text { Not covered by sectoral agreement } \\
(\text { since } 2010)\end{array}$ & $\begin{array}{l}70 \% \text { union density } \\
\text { Heavily-unionised works' council } \\
\text { Covered by sectoral agreement }\end{array}$ & $\begin{array}{l}40 \% \text { union density } \\
\text { Covered by sectoral agreement }\end{array}$ & $\begin{array}{l}70 \% \text { union density } \\
\text { Heavily-unionised works' council } \\
\text { Covered by sectoral agreement }\end{array}$ \\
\hline Agency work & Assembly line (12\%) & Assembly line (5-10\% until 2012) & Assembly line (20\%) & None \\
\hline
\end{tabular}


Table 2. Overview of collective bargaining processes and their outcomes

\begin{tabular}{|c|c|c|c|c|c|}
\hline & & \multicolumn{2}{|l|}{ ITALMETAL } & \multicolumn{2}{|l|}{ GERMETAL } \\
\hline & & IT & DE & IT & DE \\
\hline \multirow[t]{3}{*}{$\begin{array}{l}\text { Collective bargaining } \\
\text { outcomes }\end{array}$} & Agency work & $\begin{array}{l}\text { Equal pay by law } \\
\text { 2000s - 2010: ad-hoc } \\
\text { transitions to permanent } \\
\text { contracts }\end{array}$ & $\begin{array}{l}\text { Since 2005: equal pay } \\
\text { agreement and ad hoc } \\
\text { transitions to permanent } \\
\text { contracts }\end{array}$ & $\begin{array}{l}\text { Equal pay by law } \\
\text { 2000s-2014: ad-hoc } \\
\text { transitions to permanent } \\
\text { contracts, stopped due to the } \\
\text { use of staff leasing } \\
\text { Since 2017: agreement on } \\
\text { quota and transition } \\
\text { mechanisms to permanent } \\
\text { contracts after } 18 \text { months of } \\
\text { assignment }\end{array}$ & Ban \\
\hline & $\begin{array}{l}\text { On-site subcontractors } \\
\text { covering core activities } \\
\text { (production } \\
\text { engineering) }\end{array}$ & - & $\begin{array}{l}\text { Since 2015/16: inquiries on } \\
\text { costs and attempts to re- } \\
\text { internalise vehicle pasting and } \\
\text { engineering jobs }\end{array}$ & $\begin{array}{l}\text { 2013: outsourcing of quality } \\
\text { control avoided }\end{array}$ & $\begin{array}{l}\text { 2013: re-internalisation of } \\
\text { maintenance }\end{array}$ \\
\hline & $\begin{array}{lr}\text { On-site } & \text { subcontractors } \\
\text { covering } & \text { peripheral } \\
\text { activities } & \text { (industrial } \\
\text { services) } & \end{array}$ & - & - & $\begin{array}{l}\text { Since 2017: agreement } \\
\text { requiring on-site } \\
\text { subcontractors to apply } \\
\text { sectoral agreements and } \\
\text { granting information rights on } \\
\text { the use of subcontractors }\end{array}$ & $\begin{array}{l}\text { 2012: Support for the } \\
\text { formation of the works' council } \\
\text { for one logistic supplier } \\
\text { (covered by IG BAU) }\end{array}$ \\
\hline \multicolumn{2}{|c|}{ Collective bargaining mechanisms } & $\begin{array}{l}\text { Until 2010: concessions on } \\
\text { additional overtime for core } \\
\text { workers, stopped due to the } \\
\text { increase of mandatory } \\
\text { overtime through the separate } \\
\text { agreement in } 2010\end{array}$ & $\begin{array}{l}\text { Concessions on new shift } \\
\text { system and overtime for core } \\
\text { workers }\end{array}$ & $\begin{array}{l}\text { Concession on new shift } \\
\text { system and overtime for core } \\
\text { workers } \\
\text { Mobilisation of core workers }\end{array}$ & $\begin{array}{l}\text { Concessions on overtime and } \\
\text { working time flexibility for core } \\
\text { workers }\end{array}$ \\
\hline
\end{tabular}

